\title{
Current epidemiology and clinical characteristics of autoimmune liver diseases in South Korea
}

\author{
Sook-Hyang Jeong \\ Department of Internal Medicine, Seoul National University Bundang Hospital, College of Medicine, Seoul National University, Korea
}

Autoimmune liver diseases including autoimmune hepatitis (AIH) and primary biliary cholangitis (PBC) are rare diseases. The aim of this review is to examine the epidemiology and clinical characteristics of AIH and PBC in South Korea. There were 4,085 patients registered as AlH in the Rare Intractable Disease Registry of Korea between 2009-2013, with a median age of 56 years and female-to male ratio of 6.4. The age-adjusted incidence and prevalence of AlH were $1.07 / 100,000 /$ year and $4.82 / 100,000$ persons, respectively. Among the patients, $1.1 \%$ underwent liver transplantation, and case fatality was $2.18 \%$. Liver cirrhosis at diagnosis was accompanied in $23 \%$; liver biopsy was performed in $75.2 \%$, and prednisolone therapy or prednisolone and azathioprine combination therapy was done in $73 \%$ with a remission rate of $86 \%$. There were 2,824 patients with PBC ( $\geq 20$ years) registered in Korea between 2009-2013 with a median age of 57 years and female-to male ratio of 6.2. The age-adjusted incidence and prevalence of PBC were $0.86 / 100,000 /$ year and $4.75 / 100,000$ persons, respectively. Among the patients, $2.5 \%$ underwent liver transplantation, and case fatality was $2.2 \%$ with a 5 -year transplantation-free survival of $95.4 \%$. Ursodeoxycholic acid (UDCA) was prescribed in $90 \%$ of the patients with a UDCA inadequate response rate of $30 \%$. In conclusion, AIH and PBC are rare but mostly treatable diseases if diagnosed in the early stages. However, scarce data, low awareness, delayed diagnosis and non-availability of 2nd line therapeutics are important issues to be solved. Therefore, governmental support for research and drug development and nationwide cooperative studies are warranted. (Clin Mol Hepatol 2018;24:10-19)

Keywords: Autoimmune hepatitis; Primary biliary cholangitis; Simplified scoring system; Autoantibody; Liver transplantation

\section{INTRODUCTION}

Autoimmune liver disease (AILD) includes autoimmune hepatitis $(\mathrm{AlH})$, primary biliary cholangitis (PBC), primary sclerosing cholangitis, and immunoglobulin (Ig) G4 associated cholangitis. AILD is a rare disease comprising less than $2 \%$ of patients with chronic hepatitis or liver cirrhosis in Korea.' Therefore, a study on AlH or PBC generally needs to be a multicenter cooperative network, which is scarce in Korea as of yet.

Although there is no single definition for "rare disease", it was defined by either prevalence (<1,500-2,500/100,000 people) or patient number $(<20,000$ in South Korea). Since 2009, Korean

\footnotetext{
Abbreviations:

AlH, autoimmune hepatitis; $\mathrm{PBC}$, primary biliary cholangitis; UDCA Ursodeoxycholic acid; AILD, Autoimmune liver disease; Ig, immunoglobulin; RID, rare intractable diseases; HCC, hepatocellular carcinoma; KASL, The Korean Association for the study of the liver; HLA, human leukocyte antigen; IAIHG, international autoimmune hepatitis group; NAFLD, non-alcoholic fatty liver disease; ANA, anti-nuclear antibody; ALT, alanine aminotransferase; IgG, immunoglobulin G; ALP, alkaline phosphatase; GGT, gamma glutamyl transferase; SMA, Anti-smooth muscle antibody; anti-LKM1, anti-liver kidney microsomal antibody type 1; AMA, anti-mitochondrial antibody; GWAS, genome-wide association study
}

\section{Corresponding author: Sook-Hyang Jeong}

Department of Internal Medicine, Seoul National University Bundang Hospital, 82, Gumi-Ro 173 Beon-gil, Bundang-gu, Seongnam 13620, Korea Tel: +82-31-787-7029, Fax: +82-31-787-7042

E-mail: jsh@snubh.org

http://orcid.org/0000-0002-4916-7990 
National Health Insurance covering about 97\% of the total population established a registration program for rare intractable diseases (RIDs) including AlH and PBC. To be registered in this system, specific diagnostic criteria should be met by physicians, and registering in the program offers patients economic benefit such as a reduction in a proportion of the non-reimbursed fee. Therefore, using this data, studies on population-based epidemiology and clinical features of AILD can be feasible. The aim of this review is to examine the epidemiology and clinical characteristics of AlH and PBC in South Korea.

\section{CURRENT STATUS OF AIH IN SOUTH KOREA}

\section{Overview of AlH}

$\mathrm{AlH}$ is a chronic liver disease characterized by the presence of autoantibodies, hypergammaglobulinemia, and interface hepatitis on the histology of the liver biopsy. It encompasses a wide range of clinical manifestations including asymptomatic presentation, acute onset $\mathrm{AlH}$, chronic hepatitis, liver cirrhosis and hepatocellular carcinoma (HCC). Although AlH is a rare disease, it is not an intractable disease in most cases because it shows a high response rate (>80\%) to immunosuppressive therapy including glucocorticoids, and/or azathioprine, etc. However, diagnosis is not always simple, and a delayed diagnosis and missed opportunity for treatment are real problems. Except for several case reports, to date, there are only a few clinical studies on AlH in Korea.

\section{Epidemiology and genetic factors of AlH in South Korea}

According to a population-based epidemiology study on $\mathrm{AlH}$ in

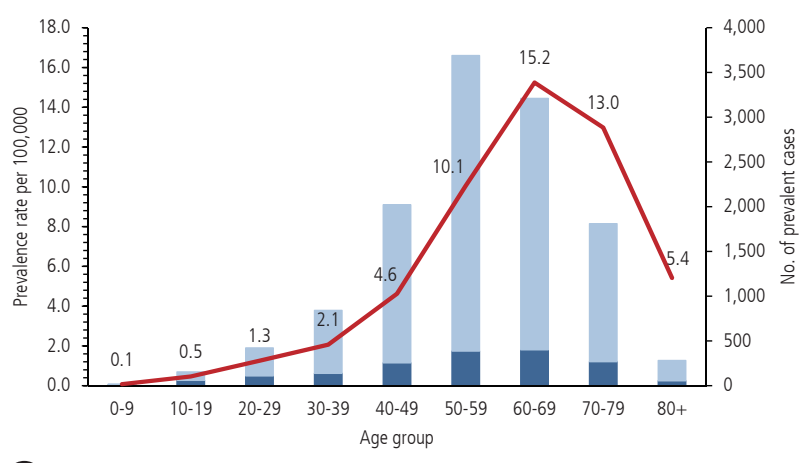

A

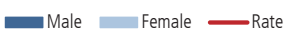

South Korea ${ }^{2}$, 4,085 patients with AIH were registered in the RID registry between 2009 and 2013, who showed a median age of 56 years and a female-to-male ratio of 6.4. The age-adjusted prevalence rate was $4.82 / 100,000$ persons (8.35 in female, 1.30 in male per 100,000 persons) (Fig. 1A), and the age-adjusted incidence rate was $1.07 / 100,000$ persons (1.83 in female, and 0.31 in male per 100,000 persons) (Fig. 1B). The prevalence of AlH in Korea seems to be lower than in Europe or North America; ${ }^{3,4}$ however, this difference may be attributable to the different study methods or genetic or environmental differences. Whether the incidence of $\mathrm{AlH}$ is increasing in Korea as seen in other regions should be studied further.

Although several genetic studies on the predisposition of $\mathrm{AlH}$ were reported globally, there is only one study on AlH patients in South Korea. Lim, et al. ${ }^{5}$ reported that the susceptibility genes to type $1 \mathrm{AIH}(\mathrm{n}=62)$ was the human leukocyte antigen (HLA) $\mathrm{DRB}^{*} 0405$ and $\mathrm{DQB} 1{ }^{*} 0401$ compared with 154 healthy controls using high-resolution sequence analysis. They also showed that the known "shared epitope" at amino acid positions 67-72 in the $3^{\text {rd }}$ hypervariable region of DR $\beta$ may be extended to amino acid positions 70-74 for better prediction of the susceptibility to AlH in Korean patients.

\section{Clinical features and diagnosis of AlH in South Korea}

The Korean Association for the study of the liver (KASL) supported 2 multicenter retrospective studies on AlH in 2002-2003 and in 2010-20137, which included 172 patients and 343 patients with $\mathrm{AlH}$, respectively. In addition, there was a single center retrospective study which included 86 AlH patients. ${ }^{8}$ The above 3 retrospective studies enrolled AlH patients whose diagnoses were based

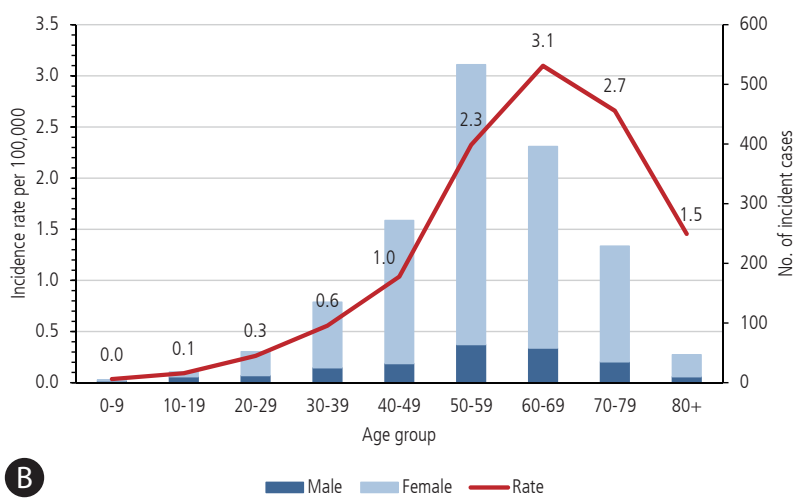

Figure 1. (A) Average annual sex-adjusted prevalence rate per hundred thousand population and prevalent cases (2009-2013) of AlH by age in South Korea. (B) Average annual sex-adjusted incidence rate per hundred thousand population and incident cases (2009-2013) of AlH by age in South Korea (adapted from $\mathrm{Kim} \mathrm{BH}$, et al. ${ }^{2}$ ). 
Table 1. Clinical characteristics of autoimmune hepatitis (AlH) in South Korea: Result of multicenter studies supported by the Korean Association for the Study of the Liver (KASL), a single center study, and a population-based study using rare intractable disease (RID) registry

\begin{tabular}{|c|c|c|c|c|}
\hline & $\begin{array}{c}\text { KASL } 1^{\text {st }} \text { Study } \\
\text { Lee JH, et al. }{ }^{6}(2004)\end{array}$ & $\begin{array}{c}\text { KASL } 2^{\text {nd }} \text { Study } \\
\text { Kim BH, et al. }{ }^{7}(2013)\end{array}$ & $\begin{array}{l}\text { Single center study } \\
\text { Kil JS, et al. } .^{8}(2010)\end{array}$ & $\begin{array}{l}\text { RID analysis study } \\
\text { Kim BH, et al. }{ }^{2} \text { (2017) }\end{array}$ \\
\hline Study design & $\begin{array}{l}\text { Retrospective, } \\
\text { multicenter }\end{array}$ & Retrospective, multicenter & $\begin{array}{l}\text { Retrospective, single } \\
\text { center }\end{array}$ & Administrative database analysis \\
\hline Year of enrollment & 1993-2004 & $2005-2009$ & $1994-2008$ & 2009-2013 \\
\hline Number of enrolled patients & 172 & 343 & 86 & 4085 \\
\hline $\begin{array}{l}\text { Diagnostic criteria } \\
\text { Definite/probable AlH }\end{array}$ & $\begin{array}{l}\text { Revised original } \\
53 \% / 47 \%\end{array}$ & $\begin{array}{l}\text { Revised original }(n=311) \\
25 \% / 65 \% \\
\text { or simplified }(n=250) \\
34 \% / 39 \%\end{array}$ & $\begin{array}{l}\text { Revised original } \\
21 \% / 79 \%\end{array}$ & $\begin{array}{l}\text { ICD-10 code registered in Rare } \\
\text { intractable disease registry }\end{array}$ \\
\hline Age (year), mean/median & 47.8 & 52.8 & $/ 51$ & 156 \\
\hline Female/male ratio & 9 & 7.3 & 5.1 & 6.4 \\
\hline $\begin{array}{l}\text { Cirrhosis at presentation } \\
\text { Acute onset } \\
\text { Asymptomatic }\end{array}$ & $22 \%$ & $\begin{array}{l}23 \% \\
46 \% \\
31 \%\end{array}$ & $\begin{array}{l}12.8 \% \\
37 \%\end{array}$ & $32.3 \%$ \\
\hline Hepatic decompensation & & $4.3 \%$ & & \\
\hline $\begin{array}{l}\text { Autoantibody positive rate } \\
\text { ANA } \\
\text { SMA } \\
\text { Anti-LKM1 } \\
\text { AMA }\end{array}$ & $\begin{array}{l}92 \% \\
31 \% \\
1 \% \\
7 \%\end{array}$ & $\begin{array}{c}94 \% \\
23 \% \\
3 \% \\
11 \%\end{array}$ & $\begin{array}{l}81.4 \% \\
44.2 \% \\
3.4 \%\end{array}$ & $\begin{array}{l}\text { Autoantibody testing rate } \\
\qquad 93.9 \% \\
81.7 \% \\
88.4 \% \\
67.5 \%\end{array}$ \\
\hline ALT (U/L), mean/median & & 284 & /182 (31-1,251) & \\
\hline $\begin{array}{l}\text { Total bilirubin }(\mathrm{mg} / \mathrm{dL}) \text {, } \\
\text { mean/median }\end{array}$ & & 4.5 & /2.3 (0.3-39) & \\
\hline $\begin{array}{l}\text { Immunoglobulin G (g/dL), } \\
\text { mean/median }\end{array}$ & $1.72 \mathrm{UNL}$ & 2,356 (1.4 UNL) & /2380 (1,330-4,640) & \\
\hline Liver biopsy performed & $74 \%$ & $\begin{array}{l}\qquad 75.2 \% \\
\text { Interface hepatitis (86\%) } \\
\text { Plasma cell (58\%) } \\
\text { Rosette (15\%) } \\
\text { Septal fibrosis/cirrhosis } \\
(20 \% / 5 \%)\end{array}$ & $70.9 \%$ & $54.2 \%$ \\
\hline Comorbidities & $\begin{array}{l}\text { Thyroid disease, } 6.4 \% \\
\text { Systemic lupus } \\
\text { erythematosus, } 3.0 \% \\
\text { Hemolytic anemia, 1.2\% } \\
\text { Primary biliary } \\
\text { cholangitis, } 0.6 \%\end{array}$ & $\begin{array}{l}\text { Thyroid disease, 18\% } \\
\text { Systemic lupus } \\
\text { erythematosus,15.2\% } \\
\text { Sjogren's syndrome, 8.0\% } \\
\text { Rheumatoid arthritis, 4.8\% } \\
\text { Raynaud's synd, 3.2\% } \\
\text { Systemic sclerosis, 2.4\% }\end{array}$ & $\begin{array}{l}\text { Rheumatoid arthritis, } \\
8.1 \% \\
\text { Thyroid disease, } 7.0 \%\end{array}$ & $\begin{array}{l}\text { Thyroid disease, } 6.9 \% \\
\text { Systemic lupus erythematosus, 3.0\% } \\
\text { Systemic sclerosis, } 1.7 \% \text {. } \\
\text { Rheumatoid arthritis, } 0.3 \% \\
\text { Dyslipidemia } 17.9 \% \\
\text { Primary biliary cholangitis, } 7.4 \%\end{array}$ \\
\hline Therapeutic regimen & & & & 2013 prescription \\
\hline Corticosteroid & $33 \%$ & $38 \%$ & $14 \%$ & Corticosteroid $44.1 \%$ \\
\hline $\begin{array}{l}\text { Corticosteroid } \\
\text { +Azathioprine }\end{array}$ & $37 \%$ & $37 \%$ & $86 \%$ & Azathioprine 38.0\% \\
\hline $\begin{array}{l}\text { Other immunosuppressive } \\
\text { therapy }\end{array}$ & $3 \%$ & & & \\
\hline $\begin{array}{l}\text { No immunosuppressive } \\
\text { therapy }\end{array}$ & $24 \%$ & $25 \%$ & & \\
\hline
\end{tabular}


Table 1. Continued

\begin{tabular}{|c|c|c|c|c|}
\hline & $\begin{array}{c}\text { KASL } 1^{\text {st }} \text { Study } \\
\text { Lee JH, et al. }{ }^{6}(2004)\end{array}$ & $\begin{array}{c}\text { KASL } 2^{\text {nd }} \text { Study } \\
\text { Kim BH, et al. }{ }^{7}(2013)\end{array}$ & $\begin{array}{l}\text { Single center study } \\
\text { Kil JS, et al. }{ }^{8}(2010)\end{array}$ & $\begin{array}{l}\text { RID analysis study } \\
\text { Kim BH, et al. }{ }^{2} \text { (2017) }\end{array}$ \\
\hline $\begin{array}{l}\text { Treatment response** } \\
\text { Remission } \\
\text { Incomplete response } \\
\text { Treatment failure } \\
\text { Relapse rate after drug. } \\
\text { withdrawal }\end{array}$ & $\begin{array}{c}(n=124) \\
70 \% \\
26 \%(n=112)\end{array}$ & $\begin{array}{c}85.7 \% \\
10.5 \% \\
3.9 \%\end{array}$ & $\begin{array}{c}83.7 \% \\
12.8 \% \\
3.5 \% \\
54.2 \%(n=24)\end{array}$ & \\
\hline $\begin{array}{l}\text { Overall survival rate } \\
5 \text { year } \\
10 \text { year } \\
\text { (median follow-up) }\end{array}$ & & & $\begin{array}{l}\text { Progression free survival } \\
\text { rate } \\
\qquad 91.2 \% \\
85.5 \% \\
\text { (43 months) }\end{array}$ & $\begin{array}{l}\text { Case fatality rate, } 6.63 \% \\
\text { during } 5 \text { years }\end{array}$ \\
\hline Liver transplantation & & & & $1.1 \%$ \\
\hline $\begin{array}{l}\text { Hepatocellular carcinoma at } \\
\text { diagnosis }\end{array}$ & & & & $0.8 \%$ \\
\hline
\end{tabular}

ALT, alanine aminotransferase; ANA, anti-nuclear antibody; SMA, anti-smooth muscle antibody; anti-LKM1, anti-liver kidney microsome type 1 antibody; AMA, anti-mitochondrial antibody.

on the revised original criteria ${ }^{9}$ or simplified criteria ${ }^{10}$ by the International Autoimmune Hepatitis Group (IAIHG), and the clinical features of AlH in the above 3 studies compared with a populationbased AlH study ${ }^{2}$ published in Korea are summarized in Table 1.

The mean or median age of AlH patients seems to be increasing from 48 years in 2000 to 56 years in 2010 at diagnosis. The female-to-male ratio was 6.4, and cirrhosis at presentation was observed in $13-32 \%$. The commonly accompanied autoimmune diseases were thyroid diseases, systemic lupus erythematosus, Sjogren's syndrome, rheumatoid arthritis and systemic sclerosis.

Liver biopsy, which is an essential procedure in the diagnosis of $\mathrm{AlH}$, was done in $54 \%-75 \%$ of the AlH patients. The applied diagnostic criteria for AlH was mostly the revised original criteria rather than the simplified criteria, and the proportion of the patients who fulfilled the definite diagnosis of $\mathrm{AlH}$ was reported from 21\%-53\%. Kim, et al. ${ }^{7}$ reported that among 343 patients, 311 were diagnosed based on the revised original criteria, and 250 were diagnosed based on the simplified criteria showing that the diagnostic sensitivity and positive predictive value of the simplified criteria compared with the revised original criteria were $69.9 \%$ and $86.4 \%$, respectively. Therefore, validation studies on the simplified criteria for the diagnosis of $\mathrm{AlH}$ in Korean patients are needed. Moreover, validation of the recently published Japanese diagnostic criteria for AlH may be interesting."

The patients with biopsy-proven non-alcoholic fatty liver disease (NAFLD) showed anti-nuclear antibody (ANA) positivity in $20 \%{ }^{12}-33 \%{ }^{13}$ and those who fulfilled the diagnostic criteria of $\mathrm{AlH}$ before liver biopsy eventually showed definitive AlH only in $8 \%{ }^{12}$ $0.5 \%{ }^{13}$ after liver biopsy. Therefore, if there are no contraindications, liver biopsy is essential to make a differential diagnosis of AlH and NAFLD with autoimmune features, especially because corticosteroids for AlH treatment may aggravate NAFLD. In a Korean study, ANA and anti-smooth muscle antibody (SMA) were positive in $5.9 \%$ and $5.1 \%$, respectively, among 135 clinically diagnosed NAFLD, and 2 patients fulfilled the diagnostic criteria of probable AlH. ${ }^{14}$ Moreover, NAFLD may potentiate AlH as shown in the cytochrome p4502D6 mouse model. ${ }^{15}$

As an atypical presentation of $\mathrm{AlH}$, acute onset $\mathrm{AlH}$ showed characteristic features including histologically centrilobular necrosis and lobular inflammation rather than portal inflammation, lower frequency of autoantibodies, lower serum immunoglobulin $\mathrm{G}$ levels, and a lower AlH score. ${ }^{16,17}$ The treatment response to corticosteroid or immunosuppressive therapy was similar to the typical cases of AlH. Therefore, being aware of this atypical presentation of AlH and treating it in a timely manner are important to stop the progression to acute liver failure.

\section{Treatment and outcomes of AlH in South Korea}

Therapeutic regimens for AlH are immunosuppressive drugs, typically corticosteroid and/or azathioprine. The benefit to harm ratio should be considered before treatment, and moderate to severe AIH reflected by high levels of ALT [ $>5 x$ upper normal limit (UNL)] or $\lg G(>2 x \mathrm{UNL}$ ) or histological activity is indication for 
immunosuppressive therapy to obtain complete biochemical and histological remission.

The initial dose of prednisolone (0.5-1 mg/ $\mathrm{kg} /$ day) and azathioprine (50 mg/day) should be adjusted in a response guided manner. ${ }^{3,4}$ In a randomized trial of AlH patients without cirrhosis, budesonide ( $9 \mathrm{mg} /$ day) and azathioprine ( $1-2 \mathrm{mg} / \mathrm{kg} /$ day) combination therapy for 6 months showed a higher rate of complete biochemical remission without steroid specific side effects (47\%) than that of prednisolone (40 mg/day tapered to $10 \mathrm{mg} /$ day) and azathioprine combination therapy (18.4\%). Therefore, budesonide can be used in non-cirrhotic AlH; however, an increased risk of portal vein thrombosis in cirrhosis, a lack of data for a dose reduction schedule, and high (90\%) first pass hepatic metabolism of budesonide should be considered. ${ }^{18}$

Corticosteroid single therapy and combination with azathioprine were done in $14-38 \%$ and $37-86 \%$ of Korean AlH patients, respectively, and about $25 \%$ of them did not receive any immunosuppressive therapy. Remission was observed in $70-86 \%$ with an incomplete response in $11-13 \%$ and treatment failure in 3-4\% (Table 1). After drug withdrawal, the relapse rate was reported as $26-54 \%$ with a median time to relapse of 4 months, but almost all of the relapsed patients responded well to the second course of immunosuppressive therapy. Therefore, the overall remission rate of immunosuppressive therapy in Korean AlH patients was about $80 \%$ showing comparable results with other countries. $3,4,11,19$

Immunosuppressive therapy should be continued for at least 3 years and for at least 2 years following complete remission of ALT and IgG. Close monitoring of adverse events related to corticosteroids or other immunosuppressive therapy is important. For azathioprine intolerant patients, mycophenolate mofetil is the second line drug of choice. Otherwise, cyclosporine or tacrolimus, infliximab or methotrexate can be used. ${ }^{3,4}$

In a longterm study on the outcome of 86 Korean AlH patients, the overall 5- and 10-year progression free survivals were $91.2 \%$ and $85.5 \%$, respectively, during a median follow-up of 43 months. Disease progression developed in 7\% (6/84) including decompensated cirrhosis (2), HCC (1) and liver-related death (3). ${ }^{8}$ Moreover, the overall case fatality rate of Korean AlH patients registered in the RID during 2009-2013 was 6.63\% showing an average annual fatality rate of $2.18 \%$. The 10 -year survival rate of Korean AlH patients seems to be similar or even better than that of Caucasian patients, which was $82 \%$ in England ${ }^{20}$ or $74.6 \%$ in Demmark $^{21}$. A recent meta-analysis showed that almost all cases of HCC developed in AlH was accompanied by cirrhosis, and the pooled incidence of HCC in cirrhotic patients at AlH diagnosis was 10.07 per 1000 patient-years supporting the HCC surveillance in AlH cirrhosis. ${ }^{22}$

Among the Korean AlH patients, 2.5\% received liver transplantation. In a single center study that included $18 \mathrm{AlH}$ patients with end stage liver disease who underwent liver transplantation, the 5 -year patient survival rate was 100\%, and the 5-year-recurrence rate of $\mathrm{AlH}$ was $17 \% .{ }^{23}$ De novo $\mathrm{AlH}$ is defined as $\mathrm{AlH}$ that develops after liver transplantation due to non-AlH causes. Among 148 Korean children who underwent liver transplantation, de novo AlH developed in 4 girls (2.7\%), and among them, ANA was positive in 3; AMA was positive in 1, and the corticosteroid with or without azathioprine response was excellent. ${ }^{24}$

\section{CURRENT STATUS OF PBC IN SOUTH KOREA}

\section{Overview of PBC}

PBC, formerly known as primary biliary cirrhosis, is a chronic autoimmune cholestatic liver disease commonly affecting middleaged women and characterized by non-suppurative intrahepatic small bile duct cholangitis and diagnostic antimitochondrial antibody (AMA) as well as responding to ursodeoxycholic acid (UDCA) rather than immunosuppressive therapy. PBC can lead to liver cirrhosis and HCC, which may require liver transplantation and decreased quality of life due to pruritus, fatigue or other symptoms.

\section{Epidemiology and genetic factors of PBC in South Korea}

According to a population-based epidemiology study on PBC in South Korea ${ }^{25}$, 2,824 patients over 20 years old with PBC were registered in the RID registry between 2009 and 2013 with a median age of 57 years and a female-to-male ratio of 6.2. The ageand sex-adjusted prevalence rate was $4.75 / 100,000$ persons (8.28 in females, 1.13 in males per 100,000 persons) (Fig. 2A), and the age- and sex-adjusted incidence rate was $0.86 / 100,000$ persons (1.41 in females, and 0.29 in males per 100,000 persons) (Fig. 2B). The prevalence of PBC in Korea seems to be lower than in Europe or North America ${ }^{26}$; however, this difference may be attributable to the different study methods, or genetic and environmental differences. Although genome-wide association studies (GWAS) on PBC from North America, Europe and Japan have 

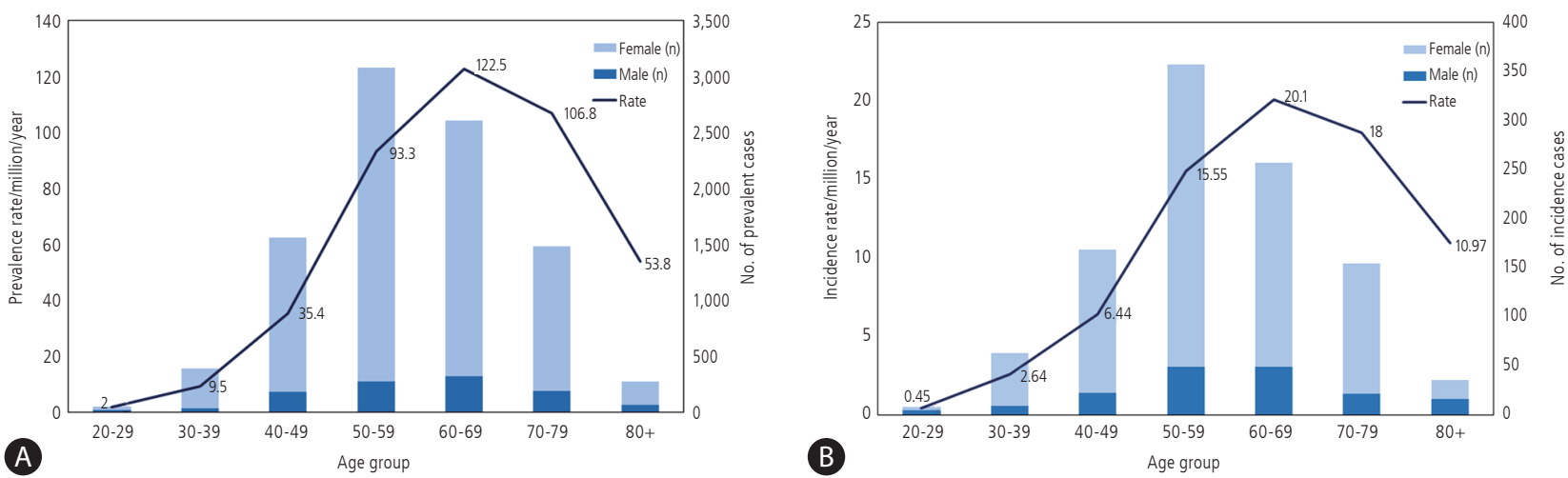

Figure 2. (A). Average annual sex-adjusted prevalence rate per million populations and prevalent case numbers of primary biliary cirrhosis by age in South Korea (2009-2013). The bars indicate the average number of total PBC cases per a year and the line indicates the prevalence rate per million. (B) Average annual sex-adjusted incidence rate per million populations and number of incident cases of primary biliary cirrhosis by age in South Korea (2011-2013). The bars indicate the number of newly diagnosed PBC cases per a year and the line indicates the incidence rate per million (adapted from Kim KA, et al. $\left.{ }^{2}\right)$.

shown that HLC class II involvement particularly at the HLA-DRB1, HLA-DQA1, and HLA-DQB1 loci is important for PBC pathogenesis, non-HLA loci predisposing to PBC such as IL12A, IL12RB2, cytotoxic T-lymphocyte-associated protein 4 and many others also have important roles in $\mathrm{PBC} .^{27}$ However, there is no genetic study on PBC in South Korea. The environmental factors related to PBC are smoking, urinary infection, hair dye and nail varnish as reported in several case-control studies. Moreover, space and time clustering of PBC within a limited geographic area over a limited period, the so called geoepidemiology in Newcastle and in New York, suggest some roles of environmental agents. ${ }^{26}$

\section{Clinical features and diagnosis of PBC in South Korea}

There is one multicenter retrospective study on PBC in South Korea $^{28}$, a single center retrospective study ${ }^{29}$ and a previously mentioned population-based study. ${ }^{25}$ The clinical features are summarized in Table 2. The mean age of adult PBC patients seemed to increase from 54 to 57 years at diagnosis during 19972013. The female-to-male ratio was 6.6-6.2, and more than $60 \%$ were asymptomatic patients, and decompensated cirrhosis at presentation was observed in $12 \%$. The commonly accompanied autoimmune diseases were hyperlipidemia, AlH (suggesting a probable overlap syndrome of AIH and PBC), thyroid diseases, Sjogren's syndrome, rheumatoid arthritis and systemic sclerosis. Liver biopsy, which is not an essential procedure in the diagnosis of $\mathrm{PBC}$, was done in $35 \%-40 \%$ of $\mathrm{PBC}$ patients. The diagnostic criteria for PBC are rather straightforward compared to AlH; therefore, administrative data may show a high similarity with retrospective data. Therefore, administrative data can be a good tool for continuous monitoring of clinical profiles of PBC in Korea.

AMA is a signature antibody for PBC diagnosis and usually tested by indirect immunofluorescence using rat kidney/stomach tissue and HEp2 cells as a substrate. There are other tests for AMA such as enzyme-linked immunosorbent assay (ELISA), line immunoassay (LIA) and fluorescent bead-based assays using a mixture of recombinant or native human E2 subunits of the 2 oxo-acid dehydrogenase complex. In a comparative study of several methods for AMA detection among 78 PBC patients and 108 control patients, use of the indirect immunofluorescence method is still reasonable with high sensitivity, although it is laborious and subjective to the observer. PBC-specific ANA, such as anti-sp100 (a nuclear pore membrane protein) and anti-gp210 (a nuclear protein identified as multiple nuclear dots) was positive only in 15\% and $22 \%$, respectively. ${ }^{30}$

\section{Treatment and outcomes of PBC in South Korea}

Lifelong administration of UDCA (13-15 mg/ $/ \mathrm{kg} /$ day) is the first line therapy for all PBC patients resulting in an improvement in liver biochemical tests, delay in disease progression, and liver transplant-free survival, especially in early stage PBC. It is very safe with minimal side effects such as hair thinning, weight gain and diarrhea. However, up to $40 \%$ of patients with PBC do not have an adequate UDCA response, and they are at greater risk of complications and disease progression. Therefore, evaluation of the UDCA response at 1 year of therapy is very important using various criteria or scores (such as the GLOBE and UK-PBC score). ${ }^{31-33}$

For the second line therapy for the PBC patients who showed an inadequate response to UDCA, bezafibrate is widely used in 
Table 2. Clinical characteristics of primary biliary cholangitis in South Korea: Result of 2 retrospective studies and a population-based study using rare intractable disease (RID) registry

\begin{tabular}{|c|c|c|c|}
\hline & $\begin{array}{l}\text { Multicenter study } \\
\text { Kim KA, et al. }{ }^{28}(2010)\end{array}$ & $\begin{array}{l}\text { Single center study } \\
\text { Park Y, et al. }{ }^{29}(2015)\end{array}$ & $\begin{array}{l}\text { RID analysis study } \\
\text { Kim KA, et al. }{ }^{25}(2016)\end{array}$ \\
\hline Study design & Retrospective, multicenter & Retrospective single center & Administrative database analysis \\
\hline Year of enrollment & 1997-2008 & 2001-2011 & $2009-2013$ \\
\hline Number of enrolled patients & 251 & 81 & 2824 (.20 year old) \\
\hline Diagnostic criteria & $\begin{array}{l}\text { Diagnostic criteria ( } \geq 2 / 3) \\
\text { 1) Elevated ALP with GGT } \\
\text { 2) AMA+ ( } \geq 1: 40) \\
\text { 3) Compatible histology }\end{array}$ & $\begin{array}{l}\text { Paris criteria }(\geq 2 / 3) \\
\text { 1) ALP }>2 \times U N L \\
\text { or GGT }>5 \times U N L \\
\text { 2) AMA+ } \\
\text { 3) florid bile duct lesion on liver } \\
\text { biopsy }\end{array}$ & $\begin{array}{l}\text { ICD-10 code registered in Rare } \\
\text { intractable disease registry }\end{array}$ \\
\hline Age (year), mean/median & 54 & 53 & 57.4 \\
\hline Female/male ratio & 6.6 & 5.2 & 6.2 \\
\hline $\begin{array}{l}\text { Cirrhosis at presentation } \\
\text { Asymptomatic }\end{array}$ & $60.6 \%$ & $23.5 \%$ & $32.3 \%$ \\
\hline Hepatic decompensation & $12.3 \%$ & & \\
\hline $\begin{array}{l}\text { Autoantibody positive rate } \\
\text { ANA } \\
\text { AMA }\end{array}$ & $\begin{array}{l}63.5 \% \\
98.4 \%\end{array}$ & $\begin{array}{l}47 \% \\
100 \%\end{array}$ & $\begin{array}{c}\text { Autoantibody testing rate } \\
74 \% \\
92.3 \%\end{array}$ \\
\hline Alkaline phosphatase, mean & $2.6 \times$ UNL & $265 \mathrm{IU} / \mathrm{L}$ & \\
\hline $\begin{array}{l}\text { Total bilirubin (mg/dL), mean/ } \\
\text { median }\end{array}$ & 1.9 & 0.9 & \\
\hline Immunoglobulin $M>1 \times U N L$ & $74 \%$ & Mean 533 mg/dL & \\
\hline Liver biopsy performed & $40 \%$ & & $35 \%$ \\
\hline Comorbidities & & & $\begin{array}{l}\text { Hyperlipidemia, } 17 \% \\
\text { Autoimmune hepatitis, } 11 \% \\
\text { Thyroid disease, } 6.5 \% \\
\text { Sjogren disease, } 0.8 \% \\
\text { Systemic lupus erythematosus, } 0.5 \% \\
\text { Systemic sclerosis, } 0.3 \% \\
\text { Rheumatoid arthritis, } 0.5 \%\end{array}$ \\
\hline $\begin{array}{l}\text { Therapy regimen } \\
\text { UDCA } \\
\text { Corticosteroid/ cyclosporine/ } \\
\text { azathioprine/ colchicine }\end{array}$ & $\begin{array}{c}(\mathrm{n}=244) \\
86 \% \\
16 \% / 7 \% / 2 \% / 0.4 \% \\
7 \%\end{array}$ & $100 \%$ & $\begin{array}{c}2013 \text { prescription } \\
93 \% \\
9 \% /-/ 5 \% /-\end{array}$ \\
\hline UDCA response at 1yr & $\begin{array}{c}(\mathrm{n}=221) \\
70 \% \text { (ALP reduction }>40 \% \text { or } \\
\text { normal range) }\end{array}$ & $\begin{array}{c}(\mathrm{n}=65) \\
\text { 72.3\% (ALP }<3 \text { xUNL, AST }<2 \mathrm{UNL}, \\
\text { Bilirubin }<1 \mathrm{mg} / \mathrm{dL})\end{array}$ & \\
\hline $\begin{array}{l}\text { Overall survival rate } \\
5 \text { year }\end{array}$ & $95 \%$ & & $\begin{array}{c}95 \% \\
\text { Case fatality rate, } 2.2 \% \text { during } 5 \text { years }\end{array}$ \\
\hline Liver transplantation & & & $2.5 \%$ \\
\hline $\begin{array}{l}\text { Hepatocellular carcinoma at } \\
\text { diagnosis }\end{array}$ & & & $1.3 \%$ \\
\hline
\end{tabular}

ALP, alkaline phosphatase; UNL, upper normal limit; GGT, gamma glutamyltransferase; AMA, anti-mitochondrial antibody; ANA, anti-nuclear antibody; UDCA, ursodeoxycholic acid. 
Japan. A small sized ( $\mathrm{n}=27)$ but longterm (110 months) prospective, randomized, controlled study reported that the combination therapy of bezafibrate and UDCA compared to UDCA monotherapy showed significantly improved biochemical liver tests and the Mayo risk score; however, the serum creatinine levels increased suggesting that the longterm safety of the combination therapy should be considered. ${ }^{34}$

The other second line drug for PBC patients with an inadequate response to UDCA is obeticholic acid with UDCA combination therapy. In a randomized placebo controlled clinical trial ${ }^{35}$, obeticholic acid with UDCA combination therapy for 12 months showed a significant improvement in biochemical liver tests compared to UDCA monotherapy, which led to the approval of obeticholic acid in the United States, Canada, and Europe. However, there were more serious adverse events with obeticholic acid such as pruritus, and a longterm study is needed. Neither bezafibrate nor obeticholic acid is approved in Korea such that nonavailability of second line therapeutics is a current unmet need.

For the symptomatic management of pruritus, cholestyramine and rifampicin at a dose of 150-300 mg daily can be used with monitoring of their toxicity. Recently, an ileal bile acid transporter inhibitor therapy for 2 weeks showed a significant reduction of pruritus with a relatively good safety profile suggesting promising frontlines for PBC management. ${ }^{36}$

The 5-, 10- and 15-year transplant-free survival rates of PBC patients were $90.0 \%, 77.5 \%$, and $65.6 \%$, respectively, in 2488 patients in North American and European countries. ${ }^{33}$ The HCC incidence in PBC patients was reported as 3.4/1000 patient-years, and the risk factors for HCC development were male, advanced disease stage, and inadequate response to UDCA.,38 Therefore, $\mathrm{HCC}$ screening is recommended for PBC patient with cirrhosis. $\mathrm{HCC}$ or end stage liver diseases due to $\mathrm{PBC}$ can be an indication for liver transplantation with a 5-year patient survival rate of $77 \%-83 \%$ and a graft survival rate of $78 \%$. Recurrence of PBC after liver transplantation occurs in $21-37 \%$ at 10 years. ${ }^{39,40}$

\section{OVERLAP SYNDROME OF AIH AND PBC IN SOUTH KOREA}

The prevalence of the AIH-PBC overlap feature is generally about $10 \%$ of adult patients with either PBC or AlH. In a single center Korean study, the prevalence of overlap syndrome was 4.7\% among patients with PBC and 7.3\% in AlH patients. ${ }^{29}$ The "Paris criteria" are the most commonly used diagnostic criteria for
AIH-PBC overlap syndrome. ${ }^{3}$ The presence of at least 2 of the 3 accepted key criteria of AlH or PBC should fulfilled which are as follows: for PBC, 1) ALP $\geq 2 x$ UNL or gGT $\geq 5 x$ UNL; 2) presence of AMA, and 3) a liver biopsy showing florid bile duct lesions; for AlH, 1) ALT $\geq 5 x$ UNL; 2) serum IgG level $\geq 2 x$ UNL or the presence of SMA, and 3) a liver biopsy showing moderate or severe periportal or periseptal lymphocytic interface hepatitis. Patients with features for both $\mathrm{PBC}$ and AlH showed a more severe disease compared to PBC or AlH alone, and combined therapy with UDCA and an immunosuppressive agent is recommended. ${ }^{3,29}$

\section{SUMMARY AND CONCLUSIONS}

There were 4,085 patients registered as AlH in the Rare Intractable Disease Registry of Korea between 2009-2013 with a median age of 56 years and a female-to male ratio of 6.4. The age-adjusted incidence and prevalence of AlH were 1.07/100,000/year and 4.82/100,000 persons, respectively. Among the patients, $1.1 \%$ underwent liver transplantation, and the case fatality was $2.18 \%$. Liver cirrhosis was accompanied in $23 \%$; liver biopsy was performed in $75.2 \%$, and prednisolone or prednisolone and azathioprine combination therapy were done in $73 \%$ with a remission rate of $86 \%$

There were 2,824 patients with PBC ( $\geq 20$ years) registered in Korea between 2009-2013 with a median age of 57 years and a female-to male ratio of 6.2. The age-adjusted incidence and the prevalence of PBC were $0.86 / 100,000 /$ year and $4.75 / 100,000$ persons, respectively. Among the patients, $2.5 \%$ underwent liver transplantation, and the case fatality was $2.2 \%$ with a 5 -year transplantation-free survival of $95.4 \%$. UDCA was prescribed in $90 \%$ of the patients, and the UDCA inadequate response rate was about $30 \%$.

In conclusion, AlH and PBC are rare but mostly treatable diseases if diagnosed in the early stages. However, scarce data on AILD, low awareness leading to a delayed diagnosis and non-availability of $2^{\text {nd }}$ line therapeutics are important issues that need to be solved. Those unmet needs concerning AlLDs should be fulfilled with governmental support for research and drug development and nationwide cooperative studies in South Korea.

\section{Conflicts of Interest}

The author has no conflicts to disclose. 


\section{REFERENCES}

1. Lee SS, Byoun YS, Jeong SH, Kim YM, Gil H, Min BY, et al. Type and cause of liver disease in Korea: single-center experience, 20052010. Clin Mol Hepatol 2012;18:309-315.

2. Kim BH, Choi HY, Ki M, Kim KA, Jang ES, Jeong SH. Populationbased prevalence, incidence, and disease burden of autoimmune hepatitis in South Korea. PLoS ONE 2017;12:e0182391.

3. European Association for the Study of the Liver. EASL clinical practice guidelines: Autoimmune hepatitis. J Hepatol 2015;63:971-1004.

4. Manns MP, Czaja AJ, Gorham JD, Krawitt EL, Mieli-Vergani G, Vergani $D$, et al. Diagnosis and management of autoimmune hepatitis. Hepatology 2010;51:2193-2213.

5. Lim YS, Oh HB, Choi SE, Kwon OJ, Heo YS, Lee HC, et al. Susceptibility to type 1 autoimmune hepatitis is associated with shared amino acid sequences at positions 70-74 of the HLA-DRB1 molecule. J Hepatol 2008;48:133-139.

6. Lee JH. [Current state of autoimmune hepatitis in Korea]. Clin Mol Hepatol 2004;10(Suppl 5):S21-S30. (Korean)

7. Kim BH, Kim YJ, Jeong SH, Tak WY, Ahn SH, Lee YJ, et al. Clinical features of autoimmune hepatitis and comparison of two diagnostic criteria in Korea: a nationwide, multicenter study. J Gastroenterol Hepatol 2013;28:128-134.

8. Kil JS, Lee JH, Han AR, Kang JY, Won HJ, Jung HY, et al. Long-term treatment outcomes for autoimmune hepatitis in Korea. J Korean Med Sci 2010;25:54-60.

9. Alvarez F, Berg PA, Bianchi FB, Bianchi L, Burroughs AK, Cancado EL, et al. International Autoimmune Hepatitis Group Report: review of criteria for diagnosis of autoimmune hepatitis. J Hepatol 1999;31:929-938.

10. Hennes EM, Zeniya M, Czaja AJ, Parés A, Dalekos GN, Krawitt EL, et al. Simplified criteria for the diagnosis of autoimmune hepatitis. Hepatology 2008;48:169-176.

11. Onji M, Zeniya M, Yamamoto K, Tsubouchi H. Autoimmune hepatitis: Diagnosis and treatment guide in Japan, 2013. Hepatol Res 2014;44:368-370.

12. Adams LA, Lindor KD, Angulo P. The prevalence of autoantibodies and atoimmune hepatitis in patients with nonalcoholic fatty liver disease. Am J Gastroenterol 2004;99:1316-1320.

13. Yatsuji S, Hashimoto E, Kaneda H, Taniai M, Tokushige K, Shiratori K. Diagnosing autoimmune hepatitis in nonalcoholic fatty liver disease: is the International Autoimmune Hepatitis Group scoring system useful? J Gastroenterol 2005;40:1130-1138.

14. Cho DH, Choi MS, Kim DH, Kim DY, Shim SG, Lee JH, et al. [A prospective study on the prevalence and clinical significance of autoantibodies in patients with suspected nonalcoholic fatty liver disease]. Korean J Hepatol 2005;11:261-267.

15. Müller $P$, Messmer $M$, Bayer $M$, Pfeilschifter JM, Hintermann $E$,
Christen U. Non-alcoholic fatty liver disease potentiates autoimmune hepatitis in the CYP2D6 mouse model. J Autoimmunity 2016;69:5158.

16. Aizawa Y, Abe H, Sugita T, Seki N, Chuganji Y, Furumoto Y, et al. Centrilobular zonal necrosis as a hallmark of a distinctive subtype of autoimmune hepatitis. Eur J Gastroenterol Hepatol 2016;28:391 397.

17. Nguyen Canh H, Harada K, Ouchi H, Sato Y, Tsuneyama K, Kage M, et al. Acute presentation of autoimmune hepatitis: a multicenter study with detailed histological evaluation in a large cohort of patients. J Clin Pathol 2017;70:961-969.

18. Manns MP, Woynarowski M, Kreisel W, Lurie Y, Rust C, Zuckerman $E$, et al. Budesonide induces remission more effectively than prednisone in a controlled trial of patients with autoimmune hepatitis. Gastroenterology 2010;139:1198-1206.

19. Chinese Society of Hepatology, Chinese Society of Gastroenterology $\&$ Chinese Society of Infectious Diseases. Chinese consensus on the diagnosis and management of autoimmune hepatitis (2015). J Dig Dis 2017; 18:247-264.

20. Hoeroldt B, McFarlane E, Dube A, Basumani P, Karajeh M, Campbell MJ, et al. Longterm outcomes of patients with autoimmune hepatitis managed at a nontransplant center. Gastroenterology 2011;140:1980-1989.

21. Gronbaek L, Vilstrup H, Jepsen P. Autoimmune hepatitis in Denmark: Incidence, prevalence, prognosis, and causes of death. A nationwide registry-based cohort study. J Hepatol 2014;60:612-617.

22. Tansel A, Katz LH, El-Serag HB, Thrift AP, Parepally M, Shakhatreh $\mathrm{MH}$, et al. Incidence and determinants of hepatocellular carcinoma in autoimmune hepatitis: a systematic review and meta-analysis. Clin Gastroenterol Hepatol 2017;15:1207-1217.

23. Cho CW, Kwon CHD, Kim JM, Choi GS, Joh JW, Lee SK. Comparative analysis of the clinical outcomes of liver transplantation for probable and definite autoimmune hepatitis by international diagnostic scoring criteria. Transplant Proc 2017;49:1126-1128.

24. Cho JM, Kim KM, Oh SH, Lee YJ, Rhee KW, Yu E. De novo autoimmune hepatitis in Korean children after liver transplantation: a single institution's experience. Transplant Proc 2011;43:2394-2396.

25. Kim KA, Ki M, Choi HY, Kim BH, Jang ES, Jeong SH. Populationbased epidemiology of primary biliary cirrhosis in South Korea. Aliment Pharmacol Ther 2016;43:154-162.

26. Griffiths L, Dyson JK, Jones DE. The new epidemiology of primary biliary cirrhosis. Semin Liver Dis 2014;34:318-328.

27. Joshita S, Umemura T, Tanaka E, Ota M. Genetic contribution to the pathogenesis of primary biliary cholangitis. J Immunol Res 2017;2017:3073504.

28. Kim KA, Jeong SH, Lee JI, Yeon JE, Lee HJ, Kwon SY, et al. [Clinical features and prognosis of primary biliary cirrhosis in Korea]. Korean J Hepatol 2010;16:139-146. 
29. Park Y, Cho Y, Cho EJ, Kim YJ. Retrospective analysis of autoimmune hepatitis-primary biliary cirrhosis overlap syndrome in Korea: characteristics, treatments, and outcomes. Clin Mol Hepatol 2015;21:150-157.

30. Han E, Jo SJ, Lee H, Choi AR, Lim J, Jung ES, et al. Clinical relevance of combined anti-mitochondrial M2 detection assays for primary biliary cirrhosis. Clin Chim Acta 2017;464:113-117.

31. European association for the study of the Liver. EASL clinical practice guidelines: The diagnosis and management of patients with primary biliary cholangitis. J Hepatol 2017;67:145-172.

32. Chen S, Duan W, You H, Jia J. A brief review on prognostic models of primary biliary cholangitis. Hepatol Int 2017;11:412-418.

33. Lammers WJ, Hirschfield GM, Corpechot C, Nevens F, Lindor KD, Janssen $\mathrm{HL}$, et al. Development and validation of a scoring system to predict outcomes of patients with primary biliary cirrhosis receiving ursodeoxycholic acid therapy. Gastrotenterology 2015;149:1804-1812.

34. Hosonuma K, Sato K, Yamazaki Y, Yanagisawa M, Hashizume H, Horiguchi $N$, et al. A prospective randomized controlled study of longterm combination therapy using ursodeoxycholic acid and bezafibrate in patients with primary biliary cirrhosis and dyslipidemia. Am J Gastroenterol 2015;110:423-431.

35 Nevens F, Andreone P, Mazzella G, Strasser SI, Bowlus C, Invernizzi P, et al. A placebo-controlled trial of obeticholic acid in primary biliary cholangitis. N Engl J Med 2016;375:631-643.

36. Hegade VS, Kendrick SF, Dobbins RL, Miller SR, Thompson D, Richards $D$, et al. Effect of ileal bile acid transporter inhibitor GSK2330672 on pruritus in primary biliary cholangitis: a doubleblind, randomized placebo-controlled, crossover, phase 2a study. Lancet, 2017;389:1114-1123.

37. Harada K, Hirohara J, Ueno Y, Nakano T, Kakuda Y, Tsubouchi H, et al. Incidence of and risk factors for hepatocellular carcinoma in primary biliary cirrhosis: National data from Japan. Hepatology 2013;57:1942-1949.

38. Trivedi PJ, Lammers WJ, van Buuren HR, Parés A, Floreani A, Janssen $\mathrm{HL}$, et al. Stratification of hepatocellular carcinoma risk in primary biliary cirrhosis; a multicenter international study. Gut 2016;65:321329.

39. Carbone M, Neuberger JM. Autoimmune liver disease, autoimmunity and liver transplantation. J Hepatol 2014;60:210-223.

40. Egawa H, Sakisaka S, Teramukai S, Sakabayashi S, Yamamoto M, Umeshita $K$, et al. Longterm outcomes of living-donor liver transplantation for primary biliary cirrhosis: A Japanese multicenter study. Am J Transplnat 2016;16:1248-1257. 